\title{
Karakteristik Jalur Pedestrian di Kawasan Blok M Jakarta
}

\author{
Azzahra Adnina Namira Ginting dan Ardy Maulidy Navastara \\ Departemen Perencanaan Wilayah dan Kota, Fakultas Teknik Sipil dan Perencanaan, Institut Teknologi \\ Sepuluh Nopember (ITS) \\ e-mail: ardy.navastara@urplan.its.ac.id
}

\begin{abstract}
Abstrak-Konsep Transit Oriented Development (TOD) pada dasarnya adalah untuk mengintegrasikan jaringan jalan dengan bangunan sekitarnya dikaitkan dengan manusia sebagai penggunanya sehingga tercipta lingkungan yang walkable, aman dan nyaman. TOD didefinisikan sebagai sebuah kawasan dengan tingkat kepadatan tinggi dengan tata guna lahan campuran (mixe-used). Pada tahun 2050 diperkirakan $70 \%$ penduduk dunia (sekitar 6,3 Milyar) akan tinggal di perkotaan (PU, 2013) urban mobility atau mobilitas perkotaan akan menjadi suatu tantangan yang besar bagi kota-kota di dunia yang tentunya membutuhkan investasi transportasi berkelanjutan untuk masa yang akan datang. Jakarta sebagai ibukota sekaligus kota terbesar di Indonesia masuk dalam kategori yang tidak walkable atau tidak ramah untuk kegiatan berjalan kaki. Dalam penelitian ini lokasi transit yang diambil yaitu Kawasan Blok M karena sebagai pusat kegiatan sekunder dengan fungsi pengembangan stasiun terpadu dan titik perpindahan beberapa moda transportasi menggunakan konsep Transit Oriented Development (TOD). Dipilihnya Blok M dikarenakan memiliki potensi dari sisi letak dan aksesibilitas yang ada, serta dengan adanya terminal yang ada dapat digabungkan dengan fungsinya, maka akan menjadi interchange antara beberapa jenis transportasi yang ada seperti transjakarta. Blok $M$ sebagai salah satu kawasan yang mendukung pengembangan tahap 1 (tahap awal) sistem MRT di Jakarta yang akan membelah dan menghubungkan Jakarta dari selatan ke utara. Untuk mencapai tujuan, dilakukan analisis untuk mengidentifikasi karakteristik jalur pedestrian di Kawasan Blok M Jakarta yaitu dilihat pada jarak dan waktu tempuh, dimensi pedestrian, kenyamanan, keamanan, kemudahan, titik origin dan destination serta konektivitas pejalan kaki. Dalam hal ini diketahui karakteristik jalur pedestrian di Kawasan Blok M Jakarta.
\end{abstract}

Kata Kunci-Pedestrian ways, dan Transit Oriented Development.

\section{PENDAHULUAN}

$\mathrm{P}$ ADA tahun 2050 diperkirakan $70 \%$ penduduk dunia (sekitar 6,3 Milyar) akan tinggal di perkotaan, urban mobility atau mobilitas perkotaan akan menjadi suatu tantangan yang besar bagi kota-kota di dunia yang tentunya membutuhkan investasi transportasi berkelanjutan untuk masa yang akan datang. Kegiatan berjalan kaki merupakan moda transportasi non-motorized yang paling efisien dan mudah diakses masyarakat, serta tidak menimbulkan dampak negatif, dengan berjalan kaki kegiatan esensial manusia untuk melakukan mobilitas dari satu tempat ketempat lainnya dapat dilakukan dengan mudah. [1]

Berjalan kaki merupakan sarana transportasi yang menghubungkan antara fungsi kawasan satu dengan yang lain terutama kawasan perdagangan, kawasan budaya, dan kawasan permukiman, dengan berjalan kaki menjadikan suatu kota menjadi lebih manusiawi. Dalam perencanaan kota, peruntukan lahan, sistem transportasi, dan sirkulasi pejalan kaki harus dibangun secara sinergis. [2] Perencanaan busway, monorel, subway/MRT, atau sarana transportasi publik lainnya harus didukung oleh moda angkutan pendukung yang menghubungkan bagian kota lainnya dengan titik-titik transit yang memiliki jalur pedestrian yang memadai, layak, dan manusiawi. Sebab, pada akhirnya semua orang tetap harus berjalan kaki untuk mencapai tempat tujuannya.

Kawasan Blok M sebagai pusat kegiatan sekunder dengan fungsi pengembangan stasiun terpadu dan titik perpindahan beberapa moda transportasi menggunakan konsep Transit Oriented Development (TOD). Konsep Transit Oriented Development (TOD) pada dasarnya adalah untuk mengintegrasikan jaringan jalan dengan bangunan sekitarnya dikaitkan dengan manusia sebagai penggunanya sehingga tercipta lingkungan yang walkable, aman dan nyaman [3]. TOD didefinisikan sebagai sebuah kawasan dengan tingkat kepadatan tinggi dengan tata guna lahan campuran (mixe-used). Kawasan mixed-use adalah keberadaan variasi kegiatan yang berbeda seperti tinggal, bekerja, belanja, dan bermain yang jaraknya berdekatan dan dapat dicapai melalui berjalan kaki.[4]

Mass Rapid Transportation (MRT) adalah layanan transportasi umum (kereta) yang beroperasi pada jalur khusus tetap atau jalur umum potensial yang terpisah yang digunakan secara eksklusif sesuai jadwal yang ditetapkan dengan rute/line yang didesain dengan perhentian-perhentian tertentu, serta dirancang untuk memindahkan sejumlah besar orang dalam waktu yang bersamaan. Blok M sebagai salah satu kawasan yang mendukung pengembangan tahap 1 (tahap awal) sistem MRT di Jakarta yang menghubungkan Jakarta dari selatan ke utara.

Hasil penelitian yang berjudul "Walkability Surveis in Asian Cities", Jakarta sebagai ibukota sekaligus kota terbesar di Indonesia masuk dalam kategori yang tidak walkable atau tidak ramah untuk kegiatan berjalan kaki. [5] Di Indonesia secara umum dan Jakarta khususnya masalah pedestrian adalah masalah yang belum dapat di atasi secara tuntas. Hal ini disebabkan karena perencanaan pedestrian sebagai bagian dari elemen sebuah kota tidak dilakukan secara menyeluruh dalam arti tidak saling kait mengkait dengan elemen-elemen perkotaan lainnya.

Berdasarkan pemaparan masalah diatas dalam mengidentifikasi karakteristik jalur pedestrian di Kawasan Blok 
M Jakarta dilakukan dengan meneliti aspek seperti jarak dan waktu tempuh, dimensi pedestrian, kenyamanan, keamanan, kemudahan, titik origin dan destination serta konektivitas pejalan kaki. Pada permasalahan yang ada terdapat sasaran dalam penelitian ini adalah mengidentifikasi karakteristik jalur pedestrian di Kawasan Blok M Jakarta untuk mengetahui jalur pedestrian di wilayah penilitan

\section{METODE}

\section{A. Jenis dan Pendekatan}

Pendekatan yang digunakan adalah pendekatan rasionalistik. Jenis penelitian dalam penelitian ini adalah deskripti kualitatif.

\section{B. Variabel}

Variabel yang digunakan untuk mengidentifikasi karakteristik jalur pedestrian di Kawasan Blok M Jakarta antara lain jarak dan waktu tempuh, dimensi pedestrian, kenyamanan, keamanan, kemudahan, titik origin dan destination serta konektivitas pejalan kaki.

\section{Mengidentifikasi Karakteristik Jalur Pedestrian di} Kawasan Blok M Jakarta

Analisis Deskriptif Kualitatif digunakan untuk mengidentifikasi karakteristik jalur pedestrian di Kawasan Blok M Jakarta dengan tahapan-tahapan dalam analisis deskriptif kualitatif adalah:

1. Pengelompokan variabel berdasarkan faktor yang sesuai dengan tinjauan pustaka

2. Melakukan survei instansional ke Badan Perencanaan dan Pembangunan DKI Jakarta, PT. MRT Jakarta dan Bina Marga Jakarta Selatan.

3. Melakukan observasi lapangan serta melakukan pembagian kuisioner kepada 96 responden yang menggunakan jalur pejalan kaki.

\section{HASIL DAN DISKUSI}

\section{A. Identifikasi Karakteristik Jalur Pedestrian di Kawasan Blok M Jakarta}

Berdasarkan hasil tinjauan pustaka didapatkan variabel-variebl untuk mengidentifikasi karakteristik jalur pedestrian di Kawasan Blok M Jakarta:

a. Aspek Jalur Pedestrian di Kawasan TOD

Faktor jalur pedestrian di Kawasan TOD terdiri dari jarak dan waktu tempuh. Pada perhitungan jarak tempuh dan waktu tempuh pada setiap blok yang di bagi menjadi sub-blok.

Tabel 1.

Jarak dan Waktu Tempuh di Kawasan Blok M Jakarta

\begin{tabular}{ccccccc}
\hline \hline Blok & $\begin{array}{c}\text { Minimal } \\
\text { Waktu } \\
\text { Tempuh } \\
\text { (menit) }\end{array}$ & $\begin{array}{c}\text { Maksimal } \\
\text { Waktu } \\
\text { Tempuh } \\
\text { (menit) }\end{array}$ & $\begin{array}{c}\text { Waktu } \\
\text { Tempuh } \\
\text { Rata-Rat } \\
\text { a (meter) }\end{array}$ & $\begin{array}{c}\text { Minimal } \\
\text { Jarak } \\
\text { Tempuh }\end{array}$ & $\begin{array}{c}\text { Maksimal } \\
\text { Jarak } \\
\text { Tempuh } \\
\text { (meter) }\end{array}$ & $\begin{array}{c}\text { Jarak } \\
\text { Tempuh } \\
\text { Rata-Rat } \\
\text { a (Meter) }\end{array}$ \\
\hline 1 & 3 & 7 & 4.71 & 250 & 550 & 385 \\
2 & 2 & 10 & 7.13 & 200 & 750 & 512 \\
3 & 2 & 7 & 4.2 & 100 & 600 & 356 \\
\hline \hline
\end{tabular}

Sumber: Ginting, 2017
Berdasarkan pada tabel di atas dapat dilihat bahwa konektivitas jalur pedetsrian di Kawasan Blok M Jakarta masih belum mendukung kegiatan di lokasi transit yang dapat mendorong pejalan kaki untuk menggunakan jalur pedestrian di dalam kawasan transit dengan jarak tempuh maksimal 400 meter dan waktu tempuh maksimal 10 menit dari dan menuju titik transit.

b. Aspek Ramah Pejalan Kaki

Faktor ramah pejalan kaki terdiri dari variabel dimensi pedestrian, kenyamanan, keamanan dan kemudahan.

Tabel 2.

Dimensi Pedestrian di Kawasan Blok M Jakarta

\begin{tabular}{|c|c|c|}
\hline Blok & Nama Jalan & $\begin{array}{c}\text { Lebar Jalur } \\
\text { Pedestrian }\end{array}$ \\
\hline 1 & Sungai Sambas 1 & - \\
\hline 1 & Sungai Sambas 2 & - \\
\hline 1 & Sungai Sambas 7 & 1 meter \\
\hline 1 & Sungai Sambar 9 & - \\
\hline 1 & Panglima Polim 1 & 2 meter \\
\hline 1 & Panglima Polim & - \\
\hline 1 & Panglima Polim Raya & 2 meter \\
\hline 1 & Bulungan & 1 meter \\
\hline 1 & Mahakam & 2 meter \\
\hline 1 & Sampit Satu & - \\
\hline 1 & Sampit 1 & - \\
\hline 1 & Sampit 2 & - \\
\hline 2 & Hasanudin Dalam & 3 meter \\
\hline 2 & Sunan Kalijaga & 4 meter \\
\hline 2 & Palatehan 1 & 3 meter \\
\hline 3 & Wijaya 7 & 2 meter \\
\hline 3 & Nusa Indah & 1 meter \\
\hline 3 & Melawai 1 & 4 meter \\
\hline 3 & Melawai 2 & 2 meter \\
\hline 3 & Melawai 3 & 2 meter \\
\hline 3 & Melawai 4 & 3 meter \\
\hline 3 & Melawai 5 & 3 meter \\
\hline 3 & Melawai 6 & 3 meter \\
\hline 3 & Melawai 7 & 3 meter \\
\hline 3 & Melawai 8 & 3 meter \\
\hline 3 & Melawai 9 & 4 meter \\
\hline 3 & Melawai 10 & - \\
\hline 3 & Melawai 11 & - \\
\hline 3 & Iskandarsyah 1 & 1 meter \\
\hline 3 & Iskandarsyah 2 & 1 meter \\
\hline 3 & Iskandarsyah Raya & 2 meter \\
\hline
\end{tabular}


Berdasarkan pada tabel di atas menjelaskan dimensi pedestrian di kawasan Blok M Jakarta, hampir rata-rata jalur pedestrian di Kawasan Blok M tidak terlayanin dengan baik. Hanya beberapa jalur pedestrian di wilayah ini yang terlayani dengan baik.

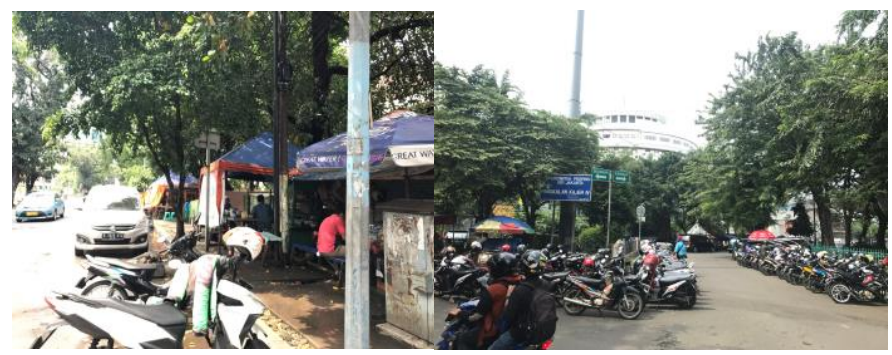

Gambar 1. Jalur Pedestrian di Kawasan Blok M Jakarta. Sumber: Ginting, 2017.

Tabel 3.

Kondisi Jalur Pedestrian di Kawasan Blok M Jakarta

\begin{tabular}{|c|c|c|c|}
\hline Blok & Keamanan & Kenyamanan & Kemudahan \\
\hline 1 & $\begin{array}{c}\text { Sebagian besar } \\
\text { pada blok ini } \\
\text { tidak dapat } \\
\text { melakukan } \\
\text { pergerakan } \\
\text { dengan leluasa } \\
\text { diakibatkan } \\
\text { tidak } \\
\text { tersediannya } \\
\text { jalur } \\
\text { pedestrian. } \\
\text { Jalur pedestrian } \\
\text { yang tersedia } \\
\text { pada blok ini } \\
\text { juga rata-rata } \\
\text { digunakan } \\
\text { menjadi tempat } \\
\text { parkir kendaran } \\
\text { serta pedagang } \\
\text { kaki lima. Oleh } \\
\text { karena itu, } \\
\text { pergerakan } \\
\text { pejalan kaki } \\
\text { terkadang harus } \\
\text { menggunakan } \\
\text { jalur kendaran } \\
\text { untuk } \\
\text { melakukan } \\
\text { pergerakan. }\end{array}$ & $\begin{array}{c}\text { Secara } \\
\text { keseluruhan, } \\
\text { untuk konteks } \\
\text { kenyamanan } \\
\text { dalam } \\
\text { pemberian rute } \\
\text { memang } \\
\text { terlayanin } \\
\text { dengan baik. } \\
\text { Walaupun sulit } \\
\text { untuk } \\
\text { mengakses jalur } \\
\text { pedestrian di } \\
\text { blok ini. }\end{array}$ & $\begin{array}{c}\text { Untuk } \\
\text { keseluruhan, } \\
\text { pejalan kaki } \\
\text { merasa } \\
\text { kesulitan } \\
\text { melakukan } \\
\text { pergerakan di } \\
\text { blok ini karena } \\
\text { bukan hanya } \\
\text { jalur pedestrian } \\
\text { yang } \\
\text { disalahgunaka } \\
\text { n tetapi juga } \\
\text { dikarenakan } \\
\text { ruang atau } \\
\text { lebar } \\
\text { pedestrian } \\
\text { yang dapat } \\
\text { dikatakan } \\
\text { sempit serta } \\
\text { permukan yang } \\
\text { tidak merata }\end{array}$ \\
\hline 2 & $\begin{array}{c}\text { Sebagian besar } \\
\text { pada blok ini, } \\
\text { pejalan kaki } \\
\text { merasa } \\
\text { terganggung } \\
\text { oleh kendaran } \\
\text { bermotor, } \\
\text { karena hampir } \\
\text { rata-rata jalur } \\
\text { pedestrian di } \\
\text { blok ini } \\
\text { disalahgunakan } \\
\text { fungsinya } \\
\text { sehingga jalur } \\
\text { pedestrian } \\
\text { harus } \\
\text { menggunakan } \\
\text { jalur kendaran } \\
\text { bermotor. }\end{array}$ & $\begin{array}{l}\text { Sebagian besar, } \\
\text { rute yang } \\
\text { diberikan } \\
\text { memang sudah } \\
\text { terlayanin } \\
\text { dengan baik. } \\
\text { Tetapi waktu } \\
\text { yang di tempuh } \\
\text { dapat dikatakan } \\
\text { tidak pendek } \\
\text { serta beberapa } \\
\text { di sub-blok di } \\
\text { blok ini } \\
\text { memiliki jarak } \\
\text { yang sangat } \\
\text { jauh ke titik } \\
\text { transit. }\end{array}$ & $\begin{array}{c}\text { Sebagian } \\
\text { besar, } \\
\text { kemudahan } \\
\text { jalur pedestrian } \\
\text { di blok ini } \\
\text { dapat } \\
\text { dikatakan } \\
\text { memadai. } \\
\text { Walaupun ada } \\
\text { beberapa } \\
\text { sub-blok di } \\
\text { blok ini masih } \\
\text { memiliki ruang } \\
\text { yang sempit } \\
\text { sehingga } \\
\text { menyusahkan } \\
\text { pejalan kaki } \\
\text { menggunakan } \\
\text { jalur pedestrian }\end{array}$ \\
\hline
\end{tabular}

\begin{tabular}{cccc}
\hline \hline Blok & Keamanan & Kenyamanan & Kemudahan \\
\hline & & Sebagian \\
besar, \\
kemudahan \\
& Secara & jalur pedestrian \\
Secara & keseluruhan, & di blok ini \\
keseluruhan & dalam memilih & dapat \\
pada blok ini & rute yang & dikatakan \\
pejalan kaki & pendek sudah & memadai. \\
tidak & tersedia pada & Walaupun ada \\
terganggung & blok ini, & beberapa \\
oleh kendaran & sehingga tidak & blok ini masih \\
bermotor & menggakibatka & memiliki ruang \\
& n kepadatan & yang sempit \\
& pejalan kaki & sehingga \\
& & menyusahkan \\
& & & pejalan kaki \\
\hline \hline
\end{tabular}

Sumber: Ginting, 2017

Berdasarkan pada hasil observasi lapangan untuk mengetahui keamanan, kenyamanan dan kemudahan di Kawasan Blok M Jakarta. Hal tersebut dapat dilihat pada setiap blok di Kawasan Blok M Jakarta.

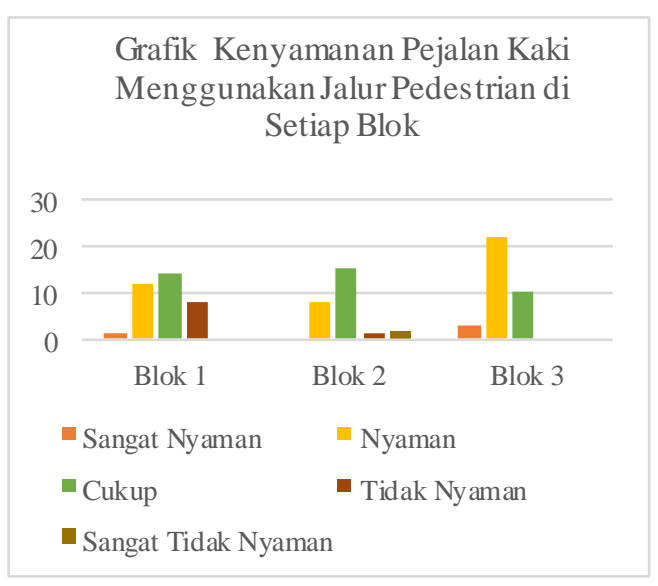

Pada grafik diatas adalah hasil kuisioner yang dibagikan kepada 96 responden yang menggunakan jalur pedestrian di Kawasan Blok M Jakarta. Dapat dilihat pejalan kaki meraasa nyaman menggunakan jalur pedestrian pada blok tertentu.

c. Ruang Publik

Faktor ruang publik terdiri-dari variabel titik origin dan destination dan konektivitas pejalan kaki. Kawasan Blok M memiliki halte atau titik transit yang memerlukan jalur pedestrian yang mempunyai konektivitas antara titik transit ke tata guna lahan di kawasan tersebut. Oleh karena itu, dilakukan pembagian kuisioner di kawasan tersebut untuk mengetahui tempat asal dan tujuan pejalan kaki di kawasan Blok M Jakarta sehari-hari. 
Titik Origin dan Destination di Blok 1

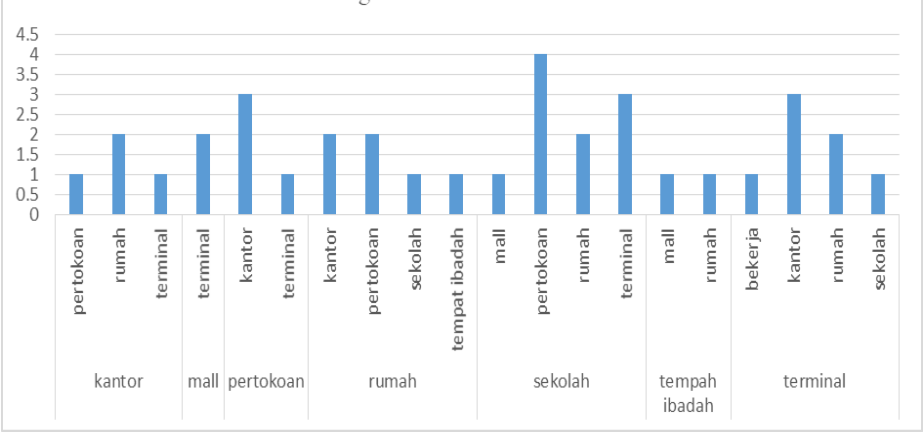

Grafik 2. Titik Origin dan Destination di Blok 1.

Sumber: Ginting, 2017.

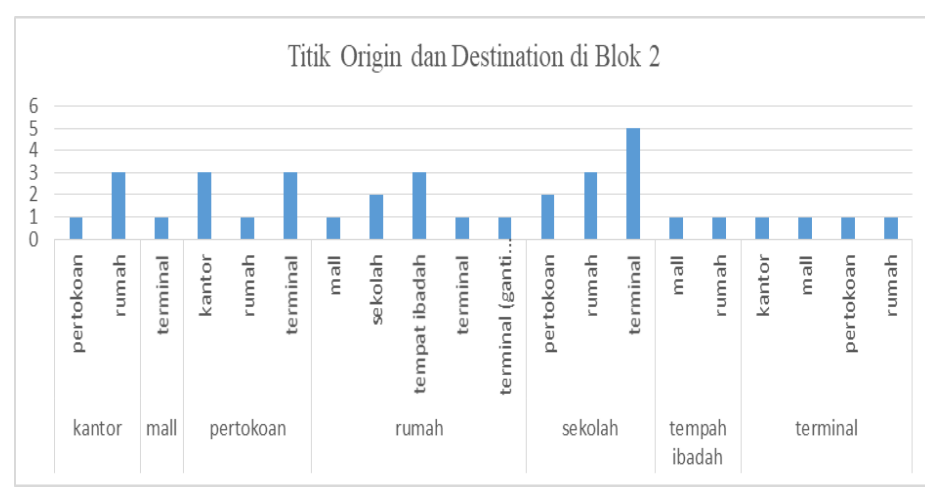

Grafik 3. Titik Origin dan Destination di Blok 2.

Sumber: Ginting, 2017.

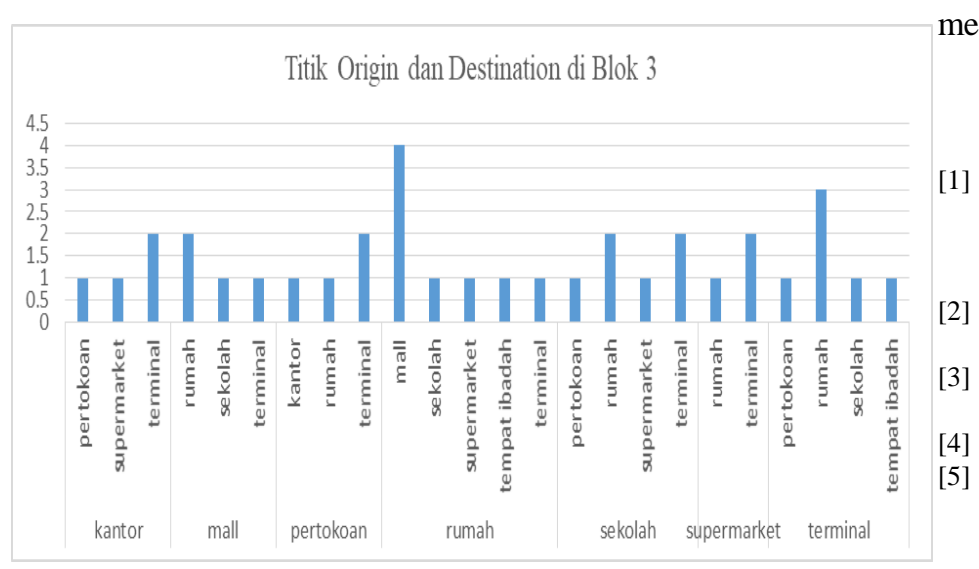

Grafik 4.Titik Origin dan Destintion di Blok 3.

Sumber: Ginting, 2017.

Berdasarkan hasil analisis diatas, diketahui bahwa pejalan kaki menggunakan jalur pedestrian pada setiap blok dari satu tempat ke tempat lain. Berdasarkan hal ini dapat dilihat dari hasil kuisioner bahwa pejalan kaki bisa menggunakan jalur pedestrian dari satu tempat ke tempat yang lainnya di sudut kawasn tersebut. Walaupun jalur pedestrian di blok-blok tersebut tidak semuannya terlayanin tetapi pejalan kaki tetap mau menggunakan jalur pedestrian.

\section{KESIMPULAN}

Penelitian ini bertujuan untuk mengidentifikasi karakterisik jalur pedestrian di kawasan Blok M Jakarta. Karakteristik jalur pedestrian di Kawasan Blok M Jakarta dapat dilihat dari aspek jarak dan waktu tempuh, dimensi pedestrian, kenyamanan, keamanan, kemudahan, titik origin dan destination dan konektivitas pejalan kaki. Pada aspek-aspek tersebut dapat dilihat dari observasi lapangan dan penyebaran kuisioner kepada 96 responden yang menggunakan jalur pedestrian.

Oleh karena itu, hasil analisis karakteristik jalur pedestrian terhadap pejalan kaki yaitu jalur pedestrian di wilayah tersebut masih tergolong sangat rendah. Pada jarak dan waktu tempuh yang tidak sesuai dengan peraturan yang ada untuk membuat jalur pedestrian tersebut menjadi ramah pejalan kaki, serta responden yang kurang merasa nyaman, aman dan mudah dalam menggunakan jalur pedestrian di wilayah peneltian.

\section{DAFTAR PUSTAKA}

Kementerian Pekerjaan Umum Republik Indonesia, Pedoman Perencanaan, Penyediaan, dan Pemanfaatan Prasarana dan Sarana Jaringan Pejalan Kaki di Kawasan Perkotaan. Jakarta: KEMENPU, 2014.

Y. Joga, N. Antar, Komedi Lenong: Satire Ruang Terbuka Hijau. Gramedia Pustaka Utama, 2007.

I. Carlton, Histories of transit-oriented development of the TOD concept. Institute of Urban \& Regional Development, 2009.

ITDP, TOD Standard v2.1. 2015.

S. Gota, Walkability Surveys In Asian Cities. Metro Manila: ADB Avenue, 2013. 